\title{
Specific language impairment in the long-term perspective - the importance of assessment procedures, reading skills, and communicative competence
}

The purpose of this study is to provide a review of the literature regarding the treatment of specific language impairment (SLI) in the long-term perspective. We develop the paper along the three issues we consider to be of the most importance in relation to counseling practice with SLI children and young people: the importance of assessment procedures of SLI, the importance of reading skills in the lives of SLI children and adults, and the importance of the quality of communication competence of SLI people for their social life. The review draws on international research mainly; however, the paper also aims to show how the three target issues are represented in the Czech research related literature.

KEY WORDS

specific language impairment; assessment procedures; reading skills; communicative and social competence 


\section{BACKGROUND}

Specific language impairment (SLI) is a serious disorder of language development affecting the lives of thousands of people around the world. Early diagnosis and intervention are considered to be of crucial importance for the future development of a child with specific language impairment. For a considerable number of children, however, SLI remains undetected throughout the preschool age (Bishop \& Mc-

Eva Richterová, Gabriela Seidlová Málková
Donald, 2009). Even when recognized, diagnosed, and treated early, such as at the preschool age, the impact on individuals' lives can still remain significant. We know that negative impacts of SLI overlap the area of language development; SLI is considered to be a general risk factor for literacy development (Durkin \& Conti-Ramsden, 2007; Isoaho, Kaupilla, \& Launonen, 2016), and difficulties in interpersonal communication affect interpersonal relationships and can very often result in emotional troubles (Macharey \& von Suchodoletz, 2008; Puglisi, Cáceres-Assenço, Nogueira, \& Befi-Lopes, 2016).

Thinking of SLI in the long-term perspective thus possibly relates to various issues. This paper aims to review the most important results and questions raised in literature around the quality of life and well-being of SLI individuals. We structure the text by addressing the three issues we consider to be of the most importance in relation to counseling practice with SLI children and young people. These are: 1) assessment criteria and procedures of SLI and its variability, 2) the importance of reading skills in the lives of SLI people, and 3) the quality of communication competence of SLI people and its impact on their social life. Each chapter of this text touches on one of the issues listed. Our intention is to also provide comments on these issues from the perspective of the Czech counseling and speech therapy practice. The final part of our paper provides thoughts and ideas which are relevant in relation to counseling practice with SLI children and young people, the practice that takes into consideration the long-term relevance of SLI children difficulties.

\section{ISSUES IN SPECIFIC LANGUAGE IMPAIRMENT ASSESSMENT PROCEDURES}

The term 'specific language impairment' is defined as a form of developmental language impairment with an estimated overall prevalence rate of $7.4 \%$ (Tomblin et al., 1997). The cognitive skills of the children with SLI are within the normal limits where there is no identifiable reason for the language impairment such as mental retardation, neurological damage, hearing deficits, or environmental deprivation (Bishop, 1992; Williams, Larkin, \& Blaggan, 2013; and oth- ers). The use of the term "specific language impairment" (SLI) is now widely accepted in the English speaking literature and professional communities (Reilly et al., 2014), and recent discussions relate instead to the specifications of the diagnostic criteria of SLI (see for example Webster \& Shavell, 2004). It should be however mentioned that the discussion around the term "specific language impairment" has recently become a serious issue again (especially in the International Journal of Language and Communication Disorders, 49), after the publication of DSM-5 (APA, 2013), where the term "specific language impairment" was not used. However, in contrast to the international research related community, the use of the term "specific language impairment" is not consistent in European countries, reflecting the national policy in education and the development of the legislation in various educational systems. For example, this is the case in the Czech Republic, where the term "developmental dysphasia" is used frequently and equally to the phrase "specific language impairment” (e.g. Smolík in Seidlová Málková \& Smolík, 2014; Tomická, 2012; Vávrů, 2010). Kucharská (2014) explains this situation by the influence of the terminology used in the current Czech educational legislation (\$16 Act. No. 561/2004 on preschool, primary, secondary, higher and other education). We believe that the problematic aspect of the use of the term "developmental dysphasia" (in contrast to the SLI notion) is that it may particularly emphasize the developmental aspect of language impairment, and may also be associated with organic brain injuries among some people, including those who are involved in the educational system.

Even though the terminology for SLI is not used in the Czech Republic consistently (and we believe also in some other European countries), Czech research and academic papers accept the definition of SLI agreed in the international community (Durdilová \& Klenková, 2014; Kucharská, 2014; Richterová \& Seidlová Málková, 2016; Seidlová Málková \& Smolík 2014; and others). Together with interested practitioners (speech therapists or school psychologists), academics and researchers all support progress towards greater acceptance of the term "specific language impairment" in the field of educational practice. Therefore, we use the term "specific language impairment" (SLI) here to refer not only to international literature, but also to the Czech and Slovak research papers (where the term "developmental dysphasia" is used).

The inconsistency in terminology relating to SLI strongly influences the educational systems, where SLI children act and are treated, and of course it has an impact on the assessment procedures used for the purpose of SLI differential assessment procedures. The assessment procedures and strategies relevant for SLI are strongly influenced by the SLI symptomatology. It is rather broad, affecting grammatical, lexi- 
cal, and phonological aspects of language processing Individuals with SLI are also considered to be quite diverse rather than a homogenous group (Hulme \& Snowling, 2009; Isoaho et al., 2015; Leonard, 2000), showing variable clinical symptoms according to the type and number of language domains affected and the scale of these difficulties. Symptoms of SLI also tend to change during the development of sufferers. Since the terminology is not unified and clinical symptoms of SLI can vary considerably, precise diagnostics of SLI are difficult to describe. No wonder then that SLI related literature struggles to agree on a unified assessment or differential assessment procedure for SLI. From the very broad perspective, assessment procedures used in relation to SLI reflect two different approaches (strategies) to understand and treat SLI: psychometric and clinical strategies.

Psychometric strategies are rooted in the use of standardized assessment tools and batteries for the detailed assessment of speech and language skills of the child. Clinical strategies invest more into detailed and individualized assessment of speech, hearing, and language and tend to involve more professionals - usually a speech therapist, psychologist, and phoniatrician. As both strategies can contribute to the best diagnostics possible, they are, ideally, to be combined. The differences between results from psychometric and clinical strategies in the assessment of SLI are frequently discussed in the literature, and they should be considered to have high importance. Tomblin et al. (1997) found that only $29 \%$ of children diagnosed with SLI on the basis of psychometric diagnostics had already been diagnosed with a language development disorder. On the other hand, Bishop and Hayiou-Thomas (2008) warn that the exclusive use of psychometric tests can lead to false positivity, where the results fulfilling the condition for SLI are actually a consequence of worsened attention or motivation. A different study found that psychometric criteria can be rather restrictive and less sensitive to language impairment than the clinical assessment of a child in its natural environment (Dunn, Flax, Sliwinski, \& Aram 1996), claiming that children diagnosed with SLI on the basis of clinical examination make more mistakes in spontaneous speech in comparison with children with normal development, regardless of whether they meet the psychometric criteria for SLI or not. Child observation in everyday situations, most crucially, can identify symptoms which might be missed by psychometric tests. A comparative study of both strategies conducted by Bishop and McDonald (2009) says that performance in language tests predicts the risk of academic failure reliably (the most reliable in this respect are short-term verbal memory span tests). However, the authors discourage the general over-reliance on the psychometric tests and advise professionals to combine the data obtained from psychometric procedures with reports from detailed interviews or assessment with the child's parents. Standardized questionnaires for parents or teachers to assess the child's communication and language abilities are used for this purpose in English speaking countries - for example Communication Checklist-CCC or CCC-2 (Norbury, Nash, Baird, \& Bishop, 2004).

Another important aspect relating to the assessment procedures of SLI is the actual manifestation of speech delay or language difficulties. This is often the first reason why parents bring their child to professionals, usually a speech therapist, and this incites the process of SLI diagnosis and treatment. However, language difficulties are not always noticeable in a child, and therefore it is not possible to start effective intervention early. Some studies warn that not every child in speech therapy fulfils the psychometric criteria of SLI (Bishop \& Hayiou-Thomas, 2008). Keegstra, Knijff, Post, and Goorhuis-Brouwer (2007) proved that from 240 preschool children treated at a speech therapy centre in the Netherlands, 35\% had normal language related abilities development (tested in language production and understanding). Aram, Morris, and Hall (1993) examined 252 preschool children (age 3 to 6) and compared the reliability and overlapping of clinical diagnosis of SLI and diagnosis of SLI for research purposes. The correspondence between clinical assessment results and the results based on psychometric procedures and tests (e.g. nonverbal intelligence score, difference between the chronological and language level related age of the child, language test score) varies considerably - between 20 and 71\%. Aram, Morris, and Hall's study (ibid.) indicates that the conclusions from clinical and psychometric assessment criteria of SLI differ vastly. Clinical approaches may be misleading, particularly in environments with a higher risk of language impairment, for example in families where some degree of speech or language impairment is already present (Bartlett et al., 2002; Bishop, 2006; Gopnik \& Crago, 1991).

From the long-term perspective, it seems to be crucial for SLI children and their families to search for those services in the educational system where both clinical and psychometric strategies are applied. Reliable screening methods should be available to different professionals (speech therapists, psychologists, special education teachers and teachers), and used for SLI risk screening. Positive results from this screening should be assessed in detail for each aspect of language and speech development.

The important preconditions for this approach, however, are: 1) an agreement at the level of definition and diagnostic criteria of SLI (as suggested by Leonard [2000]), and 2) production and publication of a quality set of psychometric tools for complex language assessment. It should be noted that some European countries may have difficulty in relation to these preconditions. That is the case of the Czech Republic. First, as already mentioned, the terminology related
A review of long-term impacts of specific language impairment 
Eva Richterová, Gabriela Seidlová Málková to SLI in both the professional and non-professional communities is not unified. Secondly, the diagnostic criteria and procedures process for SLI screening and assessment is not unified and centralized. Thirdly, clinical strategies are vastly dominant in the Czech Republic, and standardized psychometric tools for language assessment are not available. The screening relevant for SLI in the Czech educational system relates to speech development and its risks. It is usually provided by teachers in kindergartens, and also sometimes by a speech therapist in schools. A speech therapist is also typically the first one contacted by parents because of their child's persistent speech and language difficulties. Speech therapists may cooperate with teachers, a psychologist, a phoniatrician, a neurologist, or a pediatric specialist if needed. However, speech difficulties are not necessarily evident in every case of SLI (Kucharská, 2014; Tomblin et al., 1997), so some children with SLI are not identified at the preschool age, and these may only be recognized later when entering primary school. At the time of primary school entry awareness of the language and speech skills is typically raised in schools when relating to the literacy and school readiness concept in the Czech educational system. There are no clear and shared framework guidelines for Czech speech therapists (psychologist, special education teachers, or professionals in the educational system for meeting SLI) with respect to the SLI assessment criteria. Professional organizations provide training and education in courses targeting SLI issues, and methodical manuals for diagnostic processes are emerging (Fleischmannová, 2012), but the system (professional organizations, respectively) lacks connections and agreement. Generally speaking, clinical approaches are dominant, and at the same time they vary according to the background of the professional criteria meeting SLI. We think that a core issue with respect to the assessment of SLI in the Czech Republic is the lack of quality psychometric tools required for thorough SLI assessment. Large assessment batteries of language skills are available around Europe, and especially in English speaking countries, but not in the Czech Republic. It should be noted that in recent years the rate of introduction and publishing of quality standardized language assessment tools has been growing (for example Durdilová, \& Klenková, 2014; Seidlová Málková \& Smolík, 2014; Smolík, Turková, Marušicová, \& Malechová, in press), but the current situation should still be considered insufficient. Since psychometric tests are neither profitable nor appreciated as a valuable research output in academic performance evaluation, standardized tools for (not only) language and communication skills assessment are not supported. An additional issue influencing SLI treatment in Czech counseling practice is the categorization of SLI among impairments in speech and communication skills. Czech speech therapy prac- tice, especially the branch associated with school organizations, tends to focus mainly on screening and assessing the child's speech development, especially articulation. Careful descriptions of the structure of the child's language abilities (phonological, lexical and grammatical) are far less common. Therefore, an important task with respect to the long-term perspectives of SLI children in the educational system is to raise awareness among non-professionals and professionals alike that SLI should not be understood as a "mere" speech impairment which belongs solely to the speech therapy center.

\section{ISSUES ON THE IMPORTANCE OF READING SKILLS}

Children with SLI very often face serious troubles in literacy acquisition, and as a result of that also in education and vocational training in general. Current research and academic papers understand SLI as a risk factor in literacy development (Cutting \& Scarborough, 2006; Gillon, 2000; Gopnik, 1990; Hulme \& Snowling, 2009; Kucharská, 2014; Perfetti, 2007; Perfetti \& Lesgold, 1977; Smolík \& Seidlová Málková, 2014; Stanovich, 1985); however, at the same time difficulties in reading literacy acquisition are not described as the only consequence of SLI (Conti-Ramsden, Mok, Pickles, \& Durkin, 2013; Leonard, 2000; Mikulajová \& Rafajdusová, 1993). Children with SLI are typically reported to be at a higher risk of difficulties in reading literacy acquisition in comparison to control groups of the same age. The more severe language difficulties simply imply a more serious danger of reading difficulties. Catts, Fey, Tomblin, and Zhang (2002) specify that children with a history of speech-language difficulties at preschool age are at four to five times greater risk of the occurrence of reading difficulties than non-impaired children. Bishop and Adams (1990) assessed 83 children with language development difficulties for their language and literacy skills: first at the age of 4 and later when aged 8 and a half. Children whose difficulties were resolved at 5.5 years of age had no difficulties in literacy acquisition, while children with persisting verbal difficulties proved to have poor reading performance. Kucharská (2014), in a study with Czech preschool children, concluded that $65 \%$ of SLI children assessed for the first time at the age of 5.5 should be considered to be at risk of literacy acquisition issues. Scarborough \& Fowler (1993) reported that generally 40 to $75 \%$ of preschool children manifesting language or speech difficulties are at risk of difficulties with reading skills development. The risk of difficulties in literacy acquisition rises significantly with the number of affected language domains (as reported by Bishop, 2001). According to Bishop (2001), the prevalence of reading difficulties for children with issues in only 
one language domain is $29 \%$, for children with difficulties in two language domains the accompanying reading difficulties are apparent in $72 \%$ of cases, and children with three or more impaired language domains show reading difficulties in $89 \%$ of cases.

Ricketts (2011), like Chen and Vellutino (1997), assumed that difficulties in initial reading comprehension are related to weak word recognition processes, while later reading difficulties are more often the result of language skills failure (as the general reading level is increasingly more and more determined by language skills). Therefore, the reading profiles of SLI children may significantly vary according to the type of language domains affected and according to the size of the deficits in the affected language domains.

A longitudinal study by Catts et al. (2002) observed the development of reading skills in children with language impairment (both specific and nonspecific) which were previously assessed in the epidemiological study of preschool children conducted by Tomblin et al. (1997). Children were again assessed on language, reading in the second and fourth grade, and nonverbal cognitive skills in the second grade. Approximately one third of the children with language impairment had difficulties in both aspects of reading - decoding and reading comprehension - while only a small percentage of children had difficulties with decoding alone (10\% in the second grade, $12 \%$ in the fourth grade). The children who no longer met the criteria for language impairment had better reading performance than children with persistent language difficulties, but still worse than non-impaired control children. Conti-Ramsden, Botting and Durkin (2008) conducted a study with 16-year-old adolescents with a history of SLI to explore their reading profiles. Only $24 \%$ had reading skills at a good level, while the rest of the sample had some difficulties. The most commonly (47\%) impaired areas were reading skills (both reading accuracy and reading comprehension). Twenty-seven percent had difficulties solely with reading comprehension, while a mere $2 \%$ had difficulties with text decoding only.

The quality of the decoding process and early stages of reading of SLI children are often discussed in relation to the phonological skills and processes (Gillon, 2000; Hulme \& Snowling, 2009; Kucharská, 2014; Stanovich, 1985). However, the role of phonological skills in SLI children's reading profiles is not described consistently. Kelso, Fletcher, and Lee (2007) point to the significant variability of the phonological skills in SLI children manifesting insufficient reading comprehension. Some SLI children have no impaired phonological skills and do not face decoding difficulties during their early school years (Nation, Clarke, Marshall, \& Durand, 2004). More often, the reading difficulties of SLI children occur at around the time when reading comprehension becomes an important target, and things other than phonological language domains start to influence their reading skills (Bishop
\& Adams, 1990; Ricketts, 2011). The quality of reading comprehension is very much related to the grammatical language domain (resp. morphology and syntax). Morpho-syntactic language skills level are frequently discussed in children with SLI (Gopnik, 1990; Leonard, 2000; Rice, 2000; and others), and are very often considered to be one of the core indicators of this impairment. The role of memory (e.g. word recalling or word substitution, especially in words with similar meaning) is also discussed in relation to the reading skills of SLI children (Coady \& Aslin, 2003; Hulme \& Snowling, 2009). Zecker and Zinner (1987) point out that children with SLI can register the same amount of semantic information as their peers, but they suffer from worsened accessibility to this information, a more difficult process of remembering, and generally slower recall of information from their working memory.

As the large scale studies cited above confirmed, $30-50 \%$ of all SLI children face both decoding and reading comprehension difficulties. From $15 \%$ to $25 \%$ face reading difficulties only at the level of reading comprehension, and approximately $2-10 \%$ have troubles only with initial reading comprehension. This means that almost two thirds of all SLI children may face some long-lasting reading issues throughout their educational career. It is important to note that insufficient reading comprehension is especially important from the long-term perspective; it has a huge impact in the area of theoretical knowledge acquisition. If the reader does not understand the meaning of the text, the possibility to profit from it is very limited.

The negative impact of the low level reading skills of SLI youngsters on their educational outputs was confirmed in some previous studies. Cain and Oakhill (2006) found that children with a low level of reading comprehension at the age of 8 showed a significantly lower level of general education outcomes at age 11 (compared with their peers with normal reading comprehension). Dockrell, Lindsay, and Palikara (2011) report similar results for 16-year-old adolescents with a history of SLI.

SLI is widely considered as a risk factor for literacy development, and children often experience difficulties with broader academic abilities (e.g. Bishop \& Snowling, 2004; Stothard, Snowling, Bishop, Chaipchase, \& Kaplan, 1998), and it also impacts education in adulthood as much as at school age. This serious implication of SLI has also been documented in a small number of studies focusing on literacy outcomes of SLI adults. For example, Whitehouse, Line, Watt, and Bishop (2009) worked with individuals who had participated throughout their childhood in any of the six research projects conducted by Bishop and her colleagues between 1989 and 2004. The results of this study show that some deficiencies in language and literacy skills remain present in the majority of SLI people into adulthood, especially
A review of long-term impacts of specific language impairment 
Eva Richterová, Gabriela Seidlová Málková deficits in speech production, receptive grammar, verbal short-term memory, and phoneme awareness. Leonard (2000) confirmed these results. Although these studies may suggest that SLI impacts job opportunities, longitudinal studies focused on the relationship between language problems and academic or professional attainment are relatively few (Dockrell et al., 2011).

It is therefore important to point out how necessary it is to carefully explore the language and cognitive skills of SLI individuals in relation to their reading skills. The mutual relationship of these skills is a complicated matter of course, but it is an important starting point for any further intervention. The effectiveness of a combined support system related to both language and reading difficulties in children with SLI is evident from a number of studies (Acosta Rodriguez, Ramírez Santana, del Valle Hernández, \& de Castro Bermúdez, 2016; Bishop \& Edmundson, 1987; Catts et al., 2002).

The research on literacy related difficulties of SLI children in the Czech Republic does not have any tradition, and it could even be said that it has been neglected for a long time. Kucharská (2014) explains that this could be due to the fact that practitioners working with SLI children in the Czech Republic consider the speech and language problems of SLI children as being dominant and pay attention to the intervention at this level almost exclusively. Literacy difficulties of SLI children may therefore be understood as appearing incidentally. The research on development of reading skills in Czech SLI children is therefore not much supported, and in fact to the present day it is represented by only a few studies. Between 2009 and 2014 Kucharská published two related studies about the development of children at risk of difficulties in literacy development (Jagerčíková \& Kucharská, 2012; Kucharská, 2014). She followed the development of language and cognitive skills in children with typical development, children with a familiar risk of dyslexia, and children with SLI. Children were tested at six consecutive time points: from preschool age until the third year of primary school. Among others, children with SLI were the group with the most significant occurrence of 'literacy disorders'. In the first grade of primary school the SLI children were performing at a lower level in decoding, reading comprehension, and spelling when compared to other included subgroups. The differences between observed subgroups were not statistically significant. However, the differences in particular literacy skills became greater and statistically significant throughout the third grade of primary school. For example, decoding of SLI children was better than that of children with a familiar risk of dyslexia, but the reading comprehension remained the worst in the group of SLI children. The development and the structure of reading skills in SLI chil- dren were also described by Richterová and Seidlová Málková (2016). The authors compared the reading profiles of SLI children from the first and the fourth grade of primary school with the reading profiles of age controls with typical language development. The differences between the observed first grade groups were apparent, but not statistically significant, in both aspects of reading (decoding and comprehension), and were statistically significant for the measure of listening comprehension. Fourth grade SLI children's reading performance was lower than in their normally developing peers, significantly lower for listening comprehension and decoding, measured by the One minute reading and Non-word reading tasks from the Caravolas \& Volín (2005) test battery, and Listening comprehension tasks from Kucharská and Mrázková (in Kucharská et al., 2014). It should be noted here that research on SLI youngsters, adolescents, or adults in educational contexts does not exist in the Czech research literature. We believe that developmental studies on young people with SLI are especially needed for the purpose of career related counseling.

\section{ISSUES IN COMMUNICATIVE COMPETENCE AND SOCIAL DEVELOPMENT}

The third important issue that we believe relates strongly to the SLI persons' long-term perspective of well-being is the problem of the quality of their communicative competence. Poor language skills play an important role in SLI people's social development (Botting \& Conti Ramsden, 2008) and may negatively influence their self-esteem, emotional health, and quality of life in general. Research papers frequently mention that SLI children and adults face difficulties in understanding the context of communication, expressions of personal thoughts, wishes, needs, and emotions. Research shows that children with SLI have a lower degree of social competence (Lindsay \& Dockrell, 2000; Puglisi et al., 2016), especially at the level of prosocial behavior and social cognition (Bakopoulou \& Dockrell, 2016; Hart, Fujiki, Brinton, \& Hart, 2004). St Clair, Pickles, Durkin, and Conti-Ramsden (2011) reported serious difficulties in peer relationships among as many as $40 \%$ of 16 -yearold adolescents with a history of SLI. Compared to their peers, children with SLI would be more likely to be less active in social relationships, more vulnerable to conflict, and they would more likely exhibit problematic behavior in general. It is also observed that these difficulties do not disappear with age, but instead increase.

The troubles SLI people face in their social relationships could be understood by taking into consideration the importance of social background for 
the SLI persons' well-being. As Sigelman and Rider (2009) explain, so-called proximity in early years, given by neighborhood or kindergarten relationships, is understood as the key factor for friendship relationship development. Later on, more specific factors such as shared interests or similar character traits become more important for peer relationships, while adolescent years bring a need for intimacy, sharing, self-esteem, and personal identity consolidation in the context of the peer relationships. We could expect that all of the important factors of social development mentioned could be presumably affected by the language expression and reception difficulties of SLI people.

However, it may be difficult to identify causality here. Durkin and Conti-Ramsden (2007) brought an interesting insight into this problem. In their study of the quality of life in 16-year-old SLI adolescents (participants in the Manchester Language Study) and their age controls with typical language development, the SLI group reported more behavioral difficulties, emotional symptoms, and peer relationship difficulties than their age controls. The biggest difference between the groups was found in the area of peer relationship (25\% vs. $2.4 \%$ ). Another important result of the study was that participants with a lower level of receptive language skills reported behavioral and emotional difficulties more frequently. The authors also aimed to identify predictors of friendships and the quality of peer relationships. The results suggested a mutual connection of the quality of peer relationships with both expressive and receptive language skills and reading skills. However, the authors pointed out that language skills were not the most significant predictors of the quality of friendship relationships; actually their influence was quite marginal. The strongest predictors were the presence of a difficult behavior (e.g. conflicts, situationally-inappropriate responses) and the presence of prosocial behavior (e.g. cooperation, active conversational interaction) of individuals with SLI. This study brings another interesting finding. As for the subjective perception of friendship quality, there was considerable within-group heterogeneity in SLI adolescents. Many of them $(60 \%)$ perceived the quality of their friendships as good. According to the results of this study, the authors suggest that the low quality of relationships may not simply be a direct consequence of language problems, but it is an additional difficulty present in SLI which becomes more evident during adolescence. Another study assessing the relationship between language skills, behavioral problems, and the level of social competence was conducted by Puglisi et al. (2016) with Brazilian children between the ages of 6 and 11 years. Children with SLI in this study reported more behavioral problems and a lower level of social competence than their peers with typical development of language skills. Behavioral difficulties were present (reported by parents or children's caregivers) in roughly $50 \%$ of SLI children, and these involved both externalizing difficulties (such as aggression and rule breaking) and internalizing difficulties (such as anxiety, depression and somatic symptoms). The proportion of SLI children with lower social competence (such as achieving satisfactory academic skills, and engaging in activities such as sports and hobbies) was even higher - around $95 \%$.

The negative impact of SLI on social life is of course a problem for relatives and family members of SLI people (for example parents of SLI children or adults). Macharey and von Suchodoletz (2008) examined perceived stigmatization by parents of SLI children as a consequence of the language difficulties in their child. The study focused on stigmatization by other children, other adults, and family members. Approximately $50 \%$ of the parents stated that their children had experienced negative labeling, restricted contacts, and social rejection, mostly by other children. Approximately $20 \%$ of parents also felt lower acceptance of their child within their family. Around $33 \%$ of parents experienced stigmatization of themselves related to the developmental abnormalities of their children, manifested mostly in the form of disparaging remarks, avoidance of contact, or beliefs that they are responsible for their child's developmental problems. The impact of this stigmatization is serious - parents frequently tend to play down their child's problems, or they reduced their amount of social contact.

Existing research papers clearly show that SLI children and adults face (as a result of their poor language skills) a lower level of social competence in comparison to their peers. This of course has serious consequences for their social lives and relationships. Research also indicates that these difficulties are not just a short-term issue. Lower communicative competence may be a consequence of the language development difficulties of SLI children, and therefore should be considered as an important aspect of interventional procedures provided for SLI people, especially children. This of course represents a challenge to researchers, practitioners, and for the educational and counseling systems the most. It is clear that there is a need for supportive practices at the level of communicative and social competence across the lifespan of SLI individuals.

Czech research on SLI has traditionally been carried out by speech therapists and has focused predominantly on clinically relevant assessment procedures (for instance on the application of augmentative and alternative communication approaches in therapy - Bočková, 2007), or on speech therapy assessment procedures (Mlynářová, 2007; Tomická, 2012). Recently, there has been a growing number of special education oriented studies (Bočková, 2009; Kutálková, 2002) and of texts rooted in psycho-
A review of long-term impacts of specific language impairment 
linguistics (Kucharská, 2014; Smolík, 2009; Smolík \& Seidlová Málková, 2014). However, research on the relationship of communicative competencies of SLI children and their social life throughout their life span does not yet exist in the Czech research literature. We believe that this is a promising and important topic for future research in both the Czech Republic and in other European countries (as it is clear that research on this topic comes mainly from the USA and the UK).

Eva Richterová, Gabriela Seidlová Málková

\section{CONCLUSION AND SUGGESTIONS FOR THE PREVENTION OF LIFE-LONG DISADVANTAGES FOR SPECIFIC LANGUAGE IMPAIRMENT PEOPLE}

The purpose of this study was to discuss in detail issues related to the quality of life and well-being of SLI people, especially children and youngsters. We decided to aim our review at three important issues which hugely affect the education and the working career of SLI people: assessment, reading, and social communication competencies. Current research related literature now contains quite a lot of knowledge about SLI and its consequences when thinking in the life-time perspective. It is clear that SLI must be perceived as a concern, not solely in the childhood and pubescent development period, but as a language impairment with a distinct influence on a person's life and the lives of his or her closest relatives.

Our review identifies the importance of the agreement and unanimity at the level of diagnostic criteria of SLI (including its functional definition) within the educational/counseling systems of a particular country. The heterogeneity of this disorder, however, makes this a very difficult task. On the other hand, the identification of SLI at preschool age seems to be very functional when concentrating on a complex assessment of language skills and communicative competencies. It implies the need to work on the production of standardized assessment tools for SLI screening and diagnostic procedures and the need to effectively combine both clinical and psychometric strategies when working with children at risk of language development issues. This applies especially for the Czech Republic, with largely only clinical assessment procedures prevailing for the most part. Strategies and steps for strengthening cooperation between researchers and practitioners for the purpose of constructing and standardizing quality language skill assessment batteries are of high importance here. It seems to be clear that various negative consequences of SLI could be reduced by the early assessment and early and effective intervention strategies implemented within the educational system. The effort to identify children at risk of language difficulties as soon as possible (optimally at preschool age) seems to be an obvious target for counseling and speech therapy practice. This should specifically include strategies to identify those SLI children who do not face speech difficulties at preschool age, and who therefore are not typically identified before they enter primary school and face the need to become literate.

Studies on the importance of reading and communication competencies in social relationships for SLI people's lives seem to reveal a clear picture. SLI children and their families face many difficulties in their everyday lives. One example of this can be taken from the study by Conti-Ramsden et al. (2008), cited in the previous text, where the impact of SLI on literacy, educational achievement, friendships, and emotional health was monitored. Only $8 \%$ out of 139 16-year-old adolescents in this study stated that they did not feel any difficulties in any of the areas concerned, and the most severe impact of SLI was related to education and literacy. This implies that SLI children and youngsters have specific needs that should be respected in the educational and counseling process. SLI should be included among learning disorders, and its understanding as a specific learning disability should be encouraged - this is of huge importance, particularly in Czech Republic educational practice. A number of teachers have well-prepared methods for reading development, often using strategies to support reading comprehension skills (monitoring and explaining, asking text-related questions, visualization, summarization, etc.) (Armbuster, Lehr, Osborn, Adler, \& National Institute for Literacy, 2009). But very often these strategies are not related to intervention in the speech and language development of a particular child. Remediation of reading skills should be parallel and connected with the intervention in language skills. The positive influence of such strategies has already been proved in children with SLI (Acosta Rodriguez et al., 2016; Buil-Legaz, Aguilar-Mediavilla, \& Rodriguez-Ferreiro, 2016; see Hulme \& Snowling, 2011, for further notes). Furthermore, there is a need to act on interdisciplinary rooted practice for SLI children. It seems to be clear that speech therapists, psychologists, and teachers should cooperate to provide not only systematic support at the level of language (and literacy) development, but also at the level of continuous support or development of the communicative skills and social competencies of SLI people. Our review clearly shows that insufficient language skills very often negatively influence the development of reading skills, and this could lead to further difficulties in other literacy aspects (functional, financial, and digital literacy), and from a life-time perspective SLI people may lack options in both further education and career. Literacy related difficulties and troubles in educational contexts of SLI people clearly do not decline with age, and this should be understood to be an alarming point. 
Finally, counseling and clinical practice should rely on and work in relation to research teams as this enables further development at the level of quality services provided for SLI people, in particular as actors in the educational system. We identified a lot of space for further research for each of the issues we specifically analyzed for the purpose of our review. The most neglected area seems to be the research on SLI youngsters' and adults' social lives, and of course longitudinal studies of SLI people that would enable us to find out more about the manifestations of SLI in adolescence and adulthood.

\section{REFERENCES}

Acosta Rodríguez, V. M., Ramírez Santana, G. M., del Valle Hernández, N., \& de Castro Bermúdez, L. (2016). Intervention in reading processes in pupils with Specific Language Impairment (SLI). Psicothema, 28, 40-46.

American Psychiatric Association (2013). Diagnostic and Statistical Manual of Mental Disorders $\left(5^{\text {th }}\right.$ ed.). Washington, DC: Author.

Aram, D. M., Morris, R., \& Hall, N. E. (1993). Clinical and research congruence in identifying children with specific language impairment. Journal of Speech and Hearing Research, 36, 580-591.

Armbruster, B. B., Lehr, F., Osborn, J., Adler, C. R., \& National Institute for Literacy (U.S.) (2009). Put reading first: The research building blocks of reading instruction: kindergarten through grade 3 ( $3^{\text {rd }}$ ed.). Washington, D.C.: National Institute for Literacy.

Bakopoulou, I., \& Dockrell, J. E. (2016). The role of social cognition and prosocial behaviour in relation to the socio-emotional functioning of primary aged children with specific language impairment. Research in developmental disabilities, 49, 354-370.

Bartlett, Ch. W., Flax, J. F., Logue, M. W., Vieland, V. J., Basset, A. S., Tallal, P., \& Brzustowicz, L. M. (2002). A Major Susceptibility Locus for Specific Language Impairment Is Located on 13q21. American Journal of Human Genetics, 71, 45-55.

Bishop, D. V. M. (1992). The underlying nature of specific language impairment. Journal of child psychology and psychiatry, 33, 3-66.

Bishop, D. V. M. (2001). Genetic influences on language impairment and literacy problems in children: same or different? Journal of Child Psychology and Psychiatry, 42, 189-198.

Bishop, D. V. M. (2006). What causes specific language impairment in children. Association for Psychological Science, 15, 217-221.

Bishop, D. V. M., \& Adams, C. (1990). A prospective study of the relationship between specific language impairment, phonological disorders and reading retardation. Journal of Child Psychology and Psychiatry, 31, 1027-1050.
Bishop, D. V. M., \& Edmundson, A. (1987). Language-Impaired 4-Year-Olds Distinguishing Transient from Persistent Impairment. Journal of speech and hearing disorders, 52, 156-173.

Bishop, D. V. M., \& Hayiou-Thomas, M. E. (2008). Heritability of specific language impairment depends on diagnostic criteria. Genes, Brain and Behavior, 7, 365-372.

Bishop, D. V. M., \& McDonald, D. (2009). Identifying language impairment in children: combining language test scores with parental report. International Journal of Language \& Communication Disorders, 44, 600-615.

Bishop, D. V. M., \& Snowling, M. (2004). Developmental dyslexia and specific language impairment: same or different? Psychological Bulletin, 130, 858-886.

Bočková, B. (2007). Aplikace principů alternativní a augmentativní komunikace $\mathrm{v}$ terapii vývojové dysfázie [Application of principles of alternative and compensatory communication in specific language impairment therapy]. In P. Mühlpachr. Dilemata speciální pedagogiky [Dilemna in special pedagogy]. Brno: MSD.

Bočková, B (2009). Př́stupy speciálních pedagogů k podpoře žáků se specificky narušeným vývojem řeči [Special needs teachers' approaches to support of pupils with specific language impairment] (dissertation theses). Brno, Masaryk University, Faculty of Education.

Botting, N., \& Conti-Ramsden, G. (2008). The role of language, social cognition, and social skill in the functional social outcomes of young adolescents with and without history of SLI. British Journal of Developmental Psychology, 26, 281-300.

Buil-Legaz, L., Aguilar-Mediavilla, E., \& RodríguezFerreiro, J. (2016). Oral morphosyntactic competence as a predictor of reading comprehension in children with specific language impairment. International Journal of Language \& Communication Disorders, 51, 473-477.

Cain, K., \& Oakhill, J. (2006). Profiles of children with specific reading comprehension difficulties. British Journal of Educational Psychology, 76, 683-696.

Caravolas, M., \& Volín, J. (2005). Baterie diagnostických testů gramotnostních dovedností pro žáky 2. až 5. ročníků $Z \check{S}$ [The battery of diagnostic tests of literacy skills for the pupils of $2^{\text {nd }}$ to $5^{\text {th }}$ grade]. IPPP.

Catts, H. W., Fey, M. E., Tomblin, J. B., \& Zhang, X. (2002). A longitudinal investigation of reading outcomes in children with language impairments. Journal of speech, Language, and hearing Research, 5, 1142-1157.

Chen, R. S., \& Vellutino, F. R. (1997). Prediction of reading ability: A cross-validation study of the simple view of reading. Journal of Literacy Research, 29, 1-24.
A review of long-term impacts of specific language impairment 
Coady, J. A., \& Aslin, R. N. (2003). Phonological neighborhoods in the developing lexicon. Journal of child language, 30, 441-469.

Conti-Ramsden, G., Botting, N., \& Durkin, K. (2008). Parental perspectives during the transition to adulthood of adolescents with a history of specific language impairment (SLI). Journal of Speech, Language, and Hearing Research, 51, 84-96.

Conti-Ramsden, G., Mok, P. L., Pickles, A., \& Durkin, K. (2013). Adolescents with a history of spe-
Eva Richterová, Gabriela Seidlová Málková cific language impairment (SLI): Strengths and difficulties in social, emotional and behavioral functioning. Research in developmental disabilities, 34, 4161-4169.

Cutting, L. E., \& Scarborough, H. S. (2006). Prediction of reading comprehension: Relative contributions of word recognition, language proficiency, and other cognitive skills can depend on how comprehension is measured. Scientific studies of reading, 10, 277-299.

Dockrell, J., Lindsay, G., \& Palikara, O. (2011). Explaining the academy achievement at school leaving for pupils with a history of language impairment: Previous academic achievement and literacy skills. Child Language Teaching and Therapy, 27, 223-237.

Dunn, M., Flax, J., Sliwinski, M., \& Aram, D. (1996). The Use of Spontaneous Language Measures as Criteria for Identifying Children With Specific Language Impairment An Attempt to Reconcile Clinical and Research Incongruence. Journal of Speech, Language, and Hearing Research, 39, 643-654.

Durdilová, L., Klenková, J. (2014). Hodnocení slovní zásoby dětí před zahájením školní docházky [Assessment of the vocabulary in preschool children]. Praha: Karolinum.

Durkin, K., \& Conti-Ramsden, G. (2007). Language, social behavior, and the quality of friendships in adolescents with and without a history of specific language impairment. Child development, 78, 1441-1457.

Fleischmannová, H. (2012). Práce se žáky s řečovými a komunikačními poruchami [Work with pupils with speech and communication impairment] (online). Retrieved from: http://skoly.praha.eu/files/ $=84275 / \operatorname{Pr} \%$ c3\%a-1ce+s+\%c5\%be\%c3\%a1ky+s+komunika\%c4\%8dn\%c3\%admi +a + \% c5\%99e\%c4\% 8dov\%c3\%bdmi+poruchami-Mgr.+Fleischmannova. pdf

Gillon, G. T. (2000). The efficacy of phonological awareness intervention for children with spoken language impairment. Language, Speech, and Hearing Services in Schools, 31, 126-141.

Gopnik, M. (1990). Feature blindness: A case study. Language Acquisition, 1, 139-164.

Gopnik, M., \& Crago, M. B. (1991). Familial aggregation of a developmental language disorder. Cognition, 39, 1-50.
Hart, K. I., Fujiki, M., Brinton, B., \& Hart, C. H. (2004). The relationship between social behavior and severity of language impairment. Journal of Speech, Language, and Hearing Research, 47, 647-662.

Hulme, C., \& Snowling, M. J. (2009). Developmental disorders of language learning and cognition. New York: John Wiley \& Sons.

Hulme, Ch., \& Snowling, M. (2011). Children's reading comprehension difficulties: Nature, causes, and treatments. Current Directions in Psychological Science, 20, 139-142.

Isoaho, P., Kaupilla, \& T., Launonen, K. (2016). Specific language impairment (SLI) and reading development in early school years. Child Language Teaching and Therapy, 32, 1-11.

Jagerčíková, Z., \& Kucharská, A. (2012). Počátky gramotnosti u česky mluvících dětí s vývojovou dysfázií ve srovnání s běžně se vyvíjejícími vrstevníky. Počáteční gramotnost [The early literacy of Czech children with specific language impairment in comparison to typically developing children]. Pedagogika, 61, 150-163.

Keegstra, A L., Knijff, W. A., Post, W. J., \& Goorhuis-Brouwer, S. M. (2007). Children with language problems in a speech and hearing clinic: Backround variables and extent of language problems. International Journal of Pediatric Otorhinolarynglology, 71, 815-821.

Kelso K., Fletcher J., \& Lee, P. (2007). Reading comprehension in children with specific language impairment: an examination of two subgroups. International Journal of Language \& Communication Disorders, 42, 39-57.

Kucharská, A. (2014). Rizika vzniku dyslexie. Vývojové profily pregramotnostních schopností a dovedností a prekurzory gramotnosti v rizikových skupinách [The risk of dyslexia. Preliteracy skills and literacy development in high-risk groups]. Praha: PedF UK.

Kucharská, A., Seidlová Málková, G., Sotáková, H., Špačková, K., Presslerová, P., \& Richterová, E. (2014). Porozumění čtenému I. Typický vývoj porozumění čtenému - východiska, témata, zdroje - kritická analýza a návrh výzkumu [Reading comprehension I. A typical reading comprehension development - background, topics, resources - critical analysis and research proposal]. Praha: PedF UK.

Kutálková, D. (2002). Opožděný vývoj řeči [Delayed speech development]. Praha: Septima.

Leonard, L. B. (2000). Children with Specific Language Impairment. MIT Press, Cambridge, MA.

Lindsay, G., \& Dockrell, J. (2000). The behaviour and self-esteem of children with specific speech and language difficulties. British Journal of Educational Psychology, 70, 583-601.

Macharey, G., \& von Suchodoletz, W. (2008). Perceived stigmatization of children with speech-language impairment and their parents. Folia Phoniatrica et Logopaedica, 60, 256-263. 
Mikulajová, M., \& Rafajdusová, I. (1993). Vývinová dysfázia [Specific language impairment]. Bratislava: Dialóg.

Mlynářová, M. (2007). Diagnostika vývojové dysfázie ve Speciálně pedagogickém centru [Diagnostics of specific language impairment in special - education center] (dissertation theses). Masarykova Univerzita, Pedagogická fakulta.

Nation, K., Clarke, P., Marshall, C. M., \& Durand, M. (2004). Hidden Language Impairments in Children: Parallels Between Poor Reading Comprehension and Specific Language Impairment? Journal of Speech, Language, and Hearing Research, 47, 199-211.

Norbury, C. F., Nash, M., Baird, G., \& Bishop, D. V. M. (2004). Using a parental checklist to identify diagnostic groups in children with communication impairment: a validation of the Children's Communication Checklist - 2. International Journal of Language \& Communication Disorders, 39, 345-364.

Perfetti, Ch. (2007). Reading ability: Lexical quality to comprehension. Scientific studies of reading, 11, 357-383.

Perfetti, Ch. A., \& Lesgold, A. M. (1977). Discourse comprehension and sources of individual differences. Retrieved from: http://files.eric.ed.gov/fulltext/ED145400.pdf

Puglisi, M., Cáceres-Assenco, A. M., Nogueira, T., \& Befi-Lopes, D. (2016). Behavior problems and social competence in Brazilian children with specific language impairment. Psicologia: Reflexão e Critica, 29. doi: https://doi.org/10.1186/s41155-016-0027-7

Reilly, S., Tomblin, B., Law, J., McKean, C., Mensah, F. K., Morgan, A., Goldfeld S., Nicholson J. M. \& Wake, M. (2014). Specific language impairment: a convenient label for whom? International Journal of Language \& Communication Disorders, 49, 416-451.

Rice, M. L. (2000). Grammatical symptoms of specific language impairment. In D. V. M. Bishop \& L. Leonard. (eds.). Speech and language impairments in children: Causes, characteristics, intervention and outcome (pp. 17-34). Hove, East Sussex: Psychology Press.

Ricketts, J. (2011). Research review: Reading comprehension in developmental disorders of language and communication. Journal of Child Psychology and Psychiatry, 52, 1111-1123.

Richterová, E., \& Seidlová Málková, G. (2016). Čtenářské profily dětí s vývojovou dysfázií ve srovnání s typicky se vyvíjejícími vrstevníky [Reading profiles of children with specific language impairment in comparison to typicaly developing children]. E-psychologie, 10, 9-23.

Scarborough, H. S., \& Fowler, A. E. (1993). The relationship between language disorders and reading disabilities. American Speech-Language Hearing Association, Special Interests Divisions Neurophysiology Speech and Language Disorders, 3, 12-15.
Seidlová Málková, G., \& Smolík, F. (2014). Diagnostika jazykového vývoje: Diagnostická baterie pro posouzení vývoje jazykových znalostí a dovedností dětí předškolního věku [Diagnostics of language development: Diagnostics battery for the assessment of language skills development in preschool children]. Praha: Grada Publishing.

Sigelman, C. K., \& Rider, E. A. (2009). Life-span human development. Belmond, CA: Cengage Learning/Wadswordh.

Smolík, F. (2009). Vývojová dysfázie a struktura raných jazykových schopností [DoVyKo II: The development of the communication in children at the age 16 to 30 months - Questionnairen]. Československá psychologie, 53, 40-54.

Smolík, F., \& Seidlová Málková, G. (2014). Vývoj jazykových schopností v předškolním věku [Specific language impairment and the structure of early language abilities]. Praha: Grada Publishing, a.s.

Smolík, F., Turková, J., Marušincová, K., \& Malechová, V. (in press). DoVyKo II: Dotazník vývoj komunikace pro děti od 16 do 30 měsíců věku [The language skills development in preschool children]. Praha: Vydavatelství Filosofické fakulty Univerzity Karlovy.

Stanovich, K. E. (1985). Explaining the variance in reading ability in terms of psychological processes: What have we learned? Annals of Dyslexia, 35, 67-96.

St Clair, M. C., Pickles, A., Durkin, K., \& Conti-Ramsden, G. (2011). A longitudinal study of behavioral, emotional and social difficulties in individuals with a history of specific language impairment (SLI). Journal of communication disorders, 44, 186-199.

Stothard, S. E., Snowling, M. J., Bishop, D. V. M., Chipchase, B. B., \& Kaplan, C. A. (1998). Language-Impaired Preschoolers. A Follow-Up Into Adolescence. Journal of Speech, Language, and Hearing Research, 41, 407-418.

Tomblin, J. B., Records, N. L., Buckwalter, P., Zhang, X., Smith, E., \& O’Brien, M. (1997). Prevalence of Specific Language Impairment in Kindergarten Children. Journal of Speech, Language and Hearing Research, 40, 1245-1260.

Tomická, V. (2012). Narušená komunikační schopnost a čtenářská gramotnost [Impaired communication skills and reading skills]. Pedagogika, 1-2, 178-189.

Vellutino, F. R., \& Fletcher, J. M. (2007). Developmental Dyslexia. In M. J. Snowling, \& C. J. Hulme (eds.). The Science of Reading: A handbook (pp. 362-378). Oxford: Wiley/Blackwell.

Vávrů, P. (2010). Specifické symptomy vývojové dysfázie [Specific symptoms of specific language development] (diploma thesis). Univerzita Karlova, Filozofická fakulta.

Webster, R. I., \& Shavell M. I. (2004). Neurobiology of Specific Language Impairment. Journal of Child Neurology, 19, 471-481.
A review of long-term impacts of specific language impairment 
Whitehouse, A. J., Line, E. A., Watt, H. J., \& Bishop, D. V. M. (2009). Qualitative aspects of developmental language impairment relate to language and literacy outcome in adulthood. International Journal of Language \& Communication Disorders, 44, 489-510.

Williams, G. J., Larkin, R. F., \& Blaggan, S. (2013). Written language skills in children with specific language impairment. International Journal of Language \& Communication Disorders, 48, 160-171.

Eva Richterová,

Zecker, S. G., \& Zinner, T. E. (1987). Semantic code deficit for reading disabled children on an auditory lexical decision task. Journal of Reading Behavior, 19, 177-190. 